\title{
THE EXTENT OF UPSKILLING OF THE ARGENTINE LABOR MARKET: A SIMPLE ANALYSIS
}

\author{
Alexis S. Esposto* \\ Luis Federico Giménez**
}

enviado: Junio 2011- aceptado: Diciembre 2011

\begin{abstract}
Resumen
Los países industrializados evidencian un sostenido proceso de upskilling en sus mercados de trabajo durante los últimos treinta años, esto implica que la demanda laboral se ha sesgado hacia ocupaciones intensivas en habilidades y conocimiento, requiriéndose, por ende, mayor proporción de trabajadores con esas características en relación al resto. El estudio, con datos de la EPH, analiza la evolución del mercado laboral argentino verificando características de deskilling (downskilling) entre 1997 y 2009, es decir, manifiesta la ocurrencia de un proceso inverso al de las economías desarrolladas, situación que genera inequidad e impacta negativamente sobre los incentivos y competitividad del país.
\end{abstract}

Clasificación JEL: J21- J24

Palabras clave: mercado de trabajo - evolución del empleo - intensidad de conocimiento $-\mathrm{O} * \mathrm{NET}$

\footnotetext{
* Swinburne University of Technology, Melbourne, Australia. Lilydale Campus. Melba Avenue Lilydale. VIC 3140 Australia. Locked Bag 218 Lilydale. VIC 3140 Australia. e-mail: aesposto@swin.edu.au.

** Universidad Nacional de Cuyo, Mendoza, Argentina. Montevideo 127. $6^{\circ}$ piso. Dpto. 10. Mendoza, Capital (5500). e-mail: fgimenez@mendoza.gov.ar. The authors would like to acknowledge Ignacio Sarmiento from Universidad Nacional de Salta who made valuable comments in a previous version of this paper presented at the XLV Reunión de la Asociación Argentina de Economía Política (AAEP), in Buenos Aires, Noviembre de 2010.
} 


\begin{abstract}
Over the last three decades the labor market of most developed countries have experienced a sustained period of upskilling. This means an overall increase in the skill requirement of jobs determined by the demand for skilled labor. This suggests that their labor demand has become more skill intensive, shifting towards skilled workers relatively to unskilled workers. An analysis of job growth of the Argentine labor market between 1997 and 2009 using data from the EPH, evidences a process of deskilling over this period, with serious implications in terms of competitiveness and about issues related to increasing social and economic inequality.
\end{abstract}

JEL Classification: $\mathrm{J} 21-\mathrm{J} 24$

Keywords: labor force - employment change - knowledge Intensity - O*NET

\title{
INTRODUCTION
}

Since the mid-1970s, the Argentine economy has experienced an economic history characterized by extreme volatility driven by economic shocks and unsatisfactory political and economic management. Between 1964 and 1974, there was a sustained period of economic prosperity where average economic growth was 5 percent, employment grew at a constant rate and agro-industrial sectors experienced solid expansion (Müller and Lavopa, 2007). However, after 1974, this was followed by a prolonged period of socioeconomic stagnation. Müller and Lavopa (2007) argue that this period can be separated into four sub-periods characterized by: currency over-valuations (1978-81 and 1991-2000), exceedingly high external debt (1982-89), hyperinflation (1989-91) and a massive recession accompanied by the collapse of the Argentine banking system (2001-02).

Real incomes in Argentina as reported by the Encuesta Permanente de Hogares (EPH) fell by nearly 8 percent between 1992 and 1998; however, this change has not matched the growth in GDP per capita of 8.9 percent. The difference may be due to under-reporting in the EPH. Furthermore, the crisis of 2000-2002 saw a decline of nearly 40 percent in mean income as reported in the EPH, while in the preceding two years the economy experienced a phase of rapid expansion. This clearly shows the volatile nature of Argentina's economy, characterized by 
periods of rapid expansion and sharp contraction. Income changes in terms of deciles between 1992 and 2002 increased inequality. The economic crisis of 200002 impacted negatively on the whole population, although the richest decile was the least damaged in terms of income losses. The non-uniform falls in income experienced from 1992 indicate that poverty and inequality levels had increased considerably, exacerbated by the economic decline of 2000-02 (Gasparini and Cicowiez, 2007). While Argentine economic conditions appear to have improved over the last five, little is known about the skill levels of the Argentine labor force, particularly in the context that many developing and industrialised countries such as Australia and New Zealand have experienced long periods of upskilling of their respective labor forces (Esposto and Abbott, 2011). Thus, this paper seeks to answer three questions:

-Has Argentina experienced upskilling in the demand for labor or skill-bias in employment creation, and are certain job types becoming more skilled than others?

-Has this process been the same for men and women?

-What is the picture of upskilling in the Argentine labor market in terms of hours worked?

The paper is organised as follows. The following part presents the concept of upskilling and its definition and the concept of skill bias in the demand for labor. Part two presents a discussion on the data and method used for the analysis. Section three and four presents a discussion on the results, while section five presents the conclusions and areas for further research.

\section{UPSKILLING OR SKILL-BIAS IN THE DEMAND FOR LABOR}

Upskilling or skill-bias refers to an overall increase in the skill requirement of jobs and is determined by the demand for skilled labor. It suggests that the demand for labor has become more skill intensive and that there has been a shift of demand towards skilled workers relative to unskilled workers. In other words, if skill-bias is present in the labor market, then it follows that job creation has tended to favour the more skilled and this has been accompanied by a relative rise in the wages of the high-skilled relative to the less skilled (Sheehan, 2001, p. 46).

Skill-bias or upskilling is a proposition that suggests that the demand for labor has become more skill intensive and that there has been a shift in demand towards skilled workers and away from less skilled workers. Thus, if a process of upskilling is occurring, 'changes in relative employment levels (and relative 
wages) have favoured more highly skilled workers at the expense of relatively less skilled' (Wooden, 2000, p. 191).

In most studies about changes in the skill composition of labor, there seems to be consensus that nearly all OECD economies are experiencing upskilling. One way of establishing this is to look at changes in the structure of employment by occupation. Most of the international evidence points to a shift in labor demand towards the more skilled. For example, Colecchia and Papaconstantinou (1996) show that in most OECD countries in the 1980s employment grew fastest in highskilled occupations and either slowed or declined in those that required lower skill levels. Furthermore, the share of high-skilled occupations rose relative to low-skilled occupations in all countries examined. Similarly, Berman, Bound and Machin (1998) found that the demand for low-skilled workers dropped considerably in the twelve developed countries that they studied, while the proportion of skilled workers in most industries increased considerably. Acemoglu (2002) argues that in the US skill-bias has been widespread in the last 60 years and that an acceleration in skill-bias took place in the last two to three decades.

An interesting comparative case of upskilling for Argentina is Australia, given that much has been written about their socioeconomic histories and divergent economic paths (for example, Gerchunoff and Fajgelbaum, 2006; and Esposto and Thomé, 2009). For a time, the evidence upskilling for Australia was not as clear as that seen overseas. For example, Aungles et al. (1993) analyze employment growth by Australian Standard Classification of Occupations (ASCO) major group between 1971 and 1986 to investigate whether the labor market was upskilling. They decomposed employment growth by ASCO major group using a skill index that showed that employment growth favoured highly skilled occupations. This upskilling of the workforce could be seen both in terms of changes to occupational share and changes in the structure of industry (Aungles et al., 1993, p. 111). In their comparative labor market study of upskilling for the US and Australia, Dunlop and Sheehan (1998) analyzed employment change using detailed occupational data. In the case of Australia, the source data were unpublished four-digit data obtained from the Australian Bureau of Statistics (ABS) and aggregated to ASCO $1^{\text {st }}$ edition major group level. For the US, unit record data were obtained from the Current Population Survey, and these detailed occupation data were aggregated to the same eight Australian occupation groups. The data were then grouped into four skill categories, namely, white-collar high-skilled, white-collar low-skilled, bluecollar high-skilled and blue-collar low-skilled. These categories were the same as those used by Colecchia and Papaconstantinou (1996). Dunlop and Sheehan (1998) arrived at the following conclusions. Firstly, for neither country was there 
clear evidence of upskilling in aggregate over the decade to 1995, in contrast to the OECD findings reported by Colecchia and Papaconstantinou (1996). Secondly, for neither Australia nor the US was the growth rate of employment in the high-skilled category in aggregate above that for the low-skilled category. Thirdly, in spite of evidence of upskilling for women in Australia (particularly for white-collar women), there was no real evidence in either country of pronounced upskilling in the white-collar area in aggregate. For example, for the US the employment growth rates in the white-collar area were the same for high-skilled and lowskilled persons, while in Australia the differences were marginal. Furthermore, there was persistent deskilling in blue-collar jobs, with low-skilled employment growing significantly faster than high-skilled employment.

Cully (1999) examined changes to the composition of employment by using ASCO $2^{\text {nd }}$ edition major group classification of occupations and the skill hierarchy that is embedded in ASCO occupational classification. This assigns each of the major groups to one of the five skill levels. The hierarchical structure allows for the nine major occupational categories to be grouped into five skill levels.

Cully (1999) reports that over the six years all occupations experienced net employment growth, with the exception of advanced clerical and service workers. The most notable growth was seen in professionals and elementary clerical, sales and service workers. His research also found differences in growth in the pattern of employment for men and women. He then looked at the relative demand for different occupations and how these had changed over time by using ASCO $2^{\text {nd }}$ edition skill hierarchy. For all employees he reported increases in the share of employment in skill categories I and V and declines in categories II, III and IV. The analysis found similar results for men and women. Cully (1999) concluded that the change in the composition of employment favoured the most skilled and the least skilled, implying that the demand for labor had polarized.

These findings contrast with those found in the international literature: 'Australia constitutes a distinct case in experiencing relative growth in both skilled and unskilled positions' (Cully, 1999, p. 103). Wooden (2000) argues that neither the findings by Dunlop and Sheehan (1998) or by Cully (1999) are correct. To show this, he uses both aggregate employment and aggregate hours as a measure of labor demand. He justifies his methodology by pointing out that the records of employment are not often the same as labor demand for two reasons. Firstly, labor demand is often not satisfied because for some types of jobs the available supply of skills and qualifications do not match the corresponding demand. Secondly, the total number of hours worked may differ substantially across occupations, 
for example, the average hours worked by managers and administrators and professionals tend to be substantially higher than those employed in low-skilled occupations. A reason for this is that the former tend to do much more unpaid overtime work, whereas the latter are employed in occupations where the incidence of part-time employment is much higher and as a result work fewer hours. Applying the occupational categories and the skill hierarchy of ASCO $2^{\text {nd }}$ edition to both employed persons and hours worked, his results suggest that the demand for labor in Australia has considerably favoured the most skilled occupations:

"This widening gap in the demand for high-skill jobs compared with lowskill jobs is emphasized even further when the analysis is undertaken in terms of hours worked rather than the number of persons employed ... while the number of low-skill jobs has continued to rise, especially low-skill sales and service jobs, there has been virtually no growth in the total volume of low-skill work" (Wooden, 2000, p. 197).

According to Wooden (2000), the growth in the share of occupations that are low-skilled is due to the rapid increase in part-time and casual employment over the last three decades. The merit of his approach is that it draws attention to the importance of hours worked as a way of accounting for upskilling in the demand for labor. This is evident in a submission by the Commonwealth of Australia (2002) which adopted Wooden's methodology.

In a submission to the Safety Net Review on wages, the Commonwealth grouped 282 occupations into three categories - low, middle and high paid - to analyze growth in full-time employment by hours worked from 1996 to 2001. The submission found that growth in hours worked in high paid occupations accounted for 65 percent of the total, while growth in low and middle and paid occupations each accounted for 18 percent. Declines in hours worked were detected in low paid and middle paid occupations. For low paid occupations, the declines occurred amongst hospitality workers, textile, clothing and other machine operators and factory workers. In the middle paid category, the strongest declines were experienced by electrical and electronic tradespersons, intermediate plant operators and intermediate numerical clerks (Commonwealth of Australia, 2002, p. 95).

More recently Keating (2003) analyzed changes to the distribution of employment in two ways. He first looked at occupational change and found that the shift occupations has been biased towards the more highly skilled and highly paid occupations for males and females. His results are similar to those found by Wooden in terms of hours worked for the same period (1989-2000) but in terms of occupations. 


\section{I.1. A note about measuring skill and upskilling}

Measuring skill directly in terms of the content of occupations is quite a difficult task to conduct in labor market studies. A commonly used approach by economists, which is designed to provide a way of assessing skill, is reflected in the consideration given to the occupational structure of employment by analysing skill profiles in terms of the implicit skill content, and ranking them in broad occupational categories. This has been used by the OECD (1996), Colecchia and Papaconstantinou (1996) and Dunlop and Sheehan (1998). In these studies, occupations were aggregated at different levels, making up a total of four 'skill' groups: white-collar high-skilled (WCHS), white-collar low-skilled (WCLS), blue-collar high-skilled (BCHS) and blue-collar low-skilled (BCLS) (OECD, 1996, p. 82; Colecchia and Papaconstantinou, 1996, p. 8; Dunlop and Sheehan, 1998, p. 238).

In the Australian context, a number of studies have used the occupational data contained in the $1^{\text {st }}$ and $2^{\text {nd }}$ editions of the ASCO. In their analysis of occupational change Aungles et al. (1993) devise an index using ASCO $1^{\text {st }}$ edition data to show upskilling of the workforce between 1971 and 1986. Similarly, Cully (1999) and Wooden (2000) analyze upskilling of the labor force using ASCO $2^{\text {nd }}$ edition to cluster occupations into five skill categories as recommended by the ABS. The nine occupational categories of ASCO and five skill categories are detailed in Table 1. The occupational classification of ASCO is skill based and aims to cover all the occupations in the Australian workforce. In ASCO $2^{\text {nd }}$ edition the definition of skill level of an occupation is defined 'as a function of the range and complexity of the set of tasks involved' and 'the greater the range and complexity of the set of tasks, the greater the level of the occupation' (ABS, 1997, p. 5). Skill levels have been upgraded to include both formal education and/or training as well as previous experience required for entry to an occupation (ABS, 1997, p. 5). When ASCO was upgraded from the $1^{\text {st }}$ to the $2^{\text {nd }}$ edition, it left the concept of skill unchanged but refined the criteria used to measure it. These criteria measure skill level in terms of formal education and/or training and previous experience usually required for entry to an occupation (ABS, 1997, p. 5). Thus ASCO's skill measure is highly reliant on three factors: education, training and years of experience. 
Table 1 - ASCO $2^{\text {nd }}$ edition major groups and skill level

\begin{tabular}{|c|c|c|}
\hline Major groups & $\begin{array}{l}\text { Skill } \\
\text { level }\end{array}$ & Brief description \\
\hline $\begin{array}{l}\text { 1. Managers and } \\
\text { administrators } \\
\text { 2. Professionals }\end{array}$ & $\begin{array}{l}\text { I } \\
\text { I }\end{array}$ & $\begin{array}{l}\text { Most occupations in major } \\
\text { groups } 1 \text { and } 2 \text { have a skill level } \\
\text { commensurate with a bachelor } \\
\text { degree or higher qualification, or at } \\
\text { least } 5 \text { years relevant experience }\end{array}$ \\
\hline $\begin{array}{l}\text { 3. Associate } \\
\text { professionals }\end{array}$ & II & $\begin{array}{l}\text { Most occupations in major group } \\
3 \text { have a skill level commensurate } \\
\text { with an Australian Qualification } \\
\text { Framework (AQF) diploma or } \\
\text { advanced diploma, or at least } 3 \\
\text { years relevant experience }\end{array}$ \\
\hline $\begin{array}{l}\text { 4. Tradespersons and } \\
\text { related workers } \\
\text { 5. Advanced clerical } \\
\text { and service workers }\end{array}$ & III & $\begin{array}{l}\text { Most occupations in major } \\
\text { groups } 4 \text { and } 5 \text { have a skill level } \\
\text { commensurate with an AQF } \\
\text { Certificate III or IV, or at least } 3 \\
\text { years relevant experience }\end{array}$ \\
\hline $\begin{array}{l}\text { 6. Intermediate } \\
\text { clerical, sales and } \\
\text { service workers }\end{array}$ & IV & $\begin{array}{l}\text { Most occupations in major } \\
\text { groups } 6 \text { and } 7 \text { have a skill level } \\
\text { commensurate with an AQF } \\
\text { Certificate II, or at least } 1 \text { year } \\
\text { relevant experience }\end{array}$ \\
\hline $\begin{array}{l}\text { 8. Elementary } \\
\text { clerical, sales and } \\
\text { service workers } \\
\text { 9. Laborers and } \\
\text { related workers }\end{array}$ & $\mathrm{V}$ & $\begin{array}{l}\text { Most occupations in major groups } \\
8 \text { and } 9 \text { categories have a skill level } \\
\text { commensurate with completion of } \\
\text { compulsory secondary education or } \\
\text { an AQF Certificate I }\end{array}$ \\
\hline
\end{tabular}

Source: ABS (1997, p. 9). 
To measure upskilling in the labor force, for the Argentine context, we use the Clasificador Nacional de Ocupaciones $(\mathrm{CNO})^{1} 2001$ version which measures occupational complexity embodied in each occupation. It is considered to be an 'objective' feature of the work process which determines the requirements of both knowledge and skill by the persons performing a given job in the CNO classification (INDEC, 2003, p. 4). The occupational classification organizes skill into four categories: professional occupations, technical occupations, laborer occupations and non-qualified occupations. This type of classification plays a similar role to that performed by ASCO and hence can be classified as a solid proxy for skill for the purposes of this study.

As discussed above, the international literature points to upskilling of the labor force for many industrialized countries, though this has not been established or Argentina. Furthermore, the literature shows that the Argentine economy has experienced increased inequality of income and increasing poverty over a period of economic history that has been less than satisfactory (e.g. Müller and Lavopa, 2007, Gasparini and Cicowiez, 2007, Esposto and Tohmé, 2009).

\section{DATA AND METHODOLOGY USED}

To conduct this analysis, we utilize data from the EPH survey. This is Argentina's most important household survey and is conducted by the Instituto Nacional de Estadistica y Censos (INDEC) and Direcciones Provinciales de Estadísticas (DPE). ${ }^{2}$ These data provide up-to-date social indicators for the purposes of current and detailed socioeconomic understanding of the needs of a changing Argentine population. Since 1973, the EPH was conducted twice a year in the months of May and October, covering 31 urban areas and one urban rural area (INDEC, 2003, p. 3). In 2003, the survey underwent major methodological changes, including questionnaire redesign. The survey is now called EPH Continua (continuous) and provides more detailed information related to sampling errors and other sources of statistical variables. Another reason for this change was to capture more detailed information related to labor market change.

The data used in this analysis have been calibrated using the expansion weights known as 'pondera', produced by the EPHC. The methodology used to conduct this calibration follow the procedure specified by EPHC survey guidelines (INDEC, 2009).

\footnotetext{
${ }^{1}$ The CNO can be translated as the National Classification of Occupations.

${ }^{2}$ INDEC and DPE can be translated as the National Institute of Statistics and Census and Provincial Statistical Directorates.
} 


\section{IS UPSKILLING OCCURRING IN TERMS OF JOBS CREATED?}

This section presents information and analysis on whether occupations in Argentina are upskilling, becoming polarized between high-skilled and lowskilled jobs, or whether other phenomena are at play. This investigation adapts Cully's (1999) and Wooden's (2000) approach using employment data from the EPH between 1997 and 2009.

The analysis that follows is conducted over two periods, 1997-2002 and 2003-09. The reason we do this is that in 2003 the EPH changed its survey methodology, as noted above, and the authors are not aware of a concordance method that allows us to treat the EPH survey data in a continuous manner.

\section{III.1. Employment change by occupation}

The analysis that follows is made up of two parts. The first part looks at employment change by occupation. The second analyzes changes in upskilling based on the total number of hours worked in terms of occupations and in terms of skill level as defined by the CNO 2001 version.

It is important to note at the outset that the authors assume that the numbers obtained from the EPH in both surveys are a close representation of the overall Argentine labor force. The occupational analysis is conducted at the aggregate level and follows the CNO 2001 version. The CNO has ten occupations, coded from 0 to 9 . Their respective occupational names are given in the first column of Tables 2 and 3. The analysis looks at two separate periods 1997-2002 and 200309 . The reason for this distinction, as stated earlier, is that we are unable to conduct a concordance of both surveys, and secondly, because economically both periods are dramatically distinct. The first period highlights the demise of employment experienced in Argentina as a result of both the depression that began in 1998 and the financial collapse of 2001. The second shows a strong recovery fuelled by demand in primary products, one of which is the explosion in demand for soybeans from China an other parts of the world. As shown by the results reported in Table 2 between 1997 and 2002 total employment grew by 8.3 percent. Of the ten occupational categories, total employment decline was most significant in category 7 , mining, energy, construction and infrastrucuture occupations and category 2 , management, accounting and finance occupations. 
For the 2003 and 2009 period employment grew 16.6 percent nearly double the previous period, indicating a strong period of recovery, reflecting strong economic growth averaging 7.0 percent over the period. The strongest growth was seen in mining, energy and construction (41.7 percent), management (41.0 percent) and administrative, legal, planning and advanced ICT occupations (29.1 percent). Strong declines were seen in primary sector and agricultural occupations. An explanation for this sharp fall can be attributed to more technology intensive forms of production in this sector. Another contributing factor is the rise in employment in major cities such as Buenos Aires, Cordoba and Rosario where people from the country would have migrated to find new employment opportunities.

In terms of overall growth there appears to be a bias towards the demand for occupations that require higher levels of skill. We reach this conclusion on the assumption that the first three occupations are more skilled than those further down the occupational distribution. The explosion in mining, energy, construction, and infrastructure occupations is due to the expansion of China and other South East Asian economies, leading to a massive increase in the demand for commodities, which has favoured Argentina's economy.

When the occupational analysis is disaggregated in terms of men and women the trends for both periods were quite similar. For the period 2003-09, growth in employment for men (17.9 percent) was stronger than women (14.9 percent), and the trends were similar to those seen in total employment growth.

When we look at total employment growth in terms of shares for 2003-09, we can see a bias in employment growth towards occupations requiring higher skill levels. This can be seen in the share increase for management and administrative occupations. This trend is almost the same for men and as for women. This is in stark contrast to a period of downskilling in terms of job creation for the 1997-2002 period, where clear trends of downskilling occurred (see Table 2 columns 4 and 8).

Of more interest is the change in the shares from 1997 to 2009. Figure 1 highlights a process of stagnant employment growth or deskilling in terms of shares growth. Over this period, the share in employment declined in eight of the ten $\mathrm{CNO}$ listing of occupations. Only two occupations experienced increases, namely, management and basic social services. These can be regarded as requiring high and medium level skills, respectively. All other occupations experienced declines in their shares, indicating at least a process of 'skill stagnation' or even deskilling, particularly in jobs that require medium skill to high level skills. 
Figure 1- Total employment shares by occupation, Argentina, 1997-2009

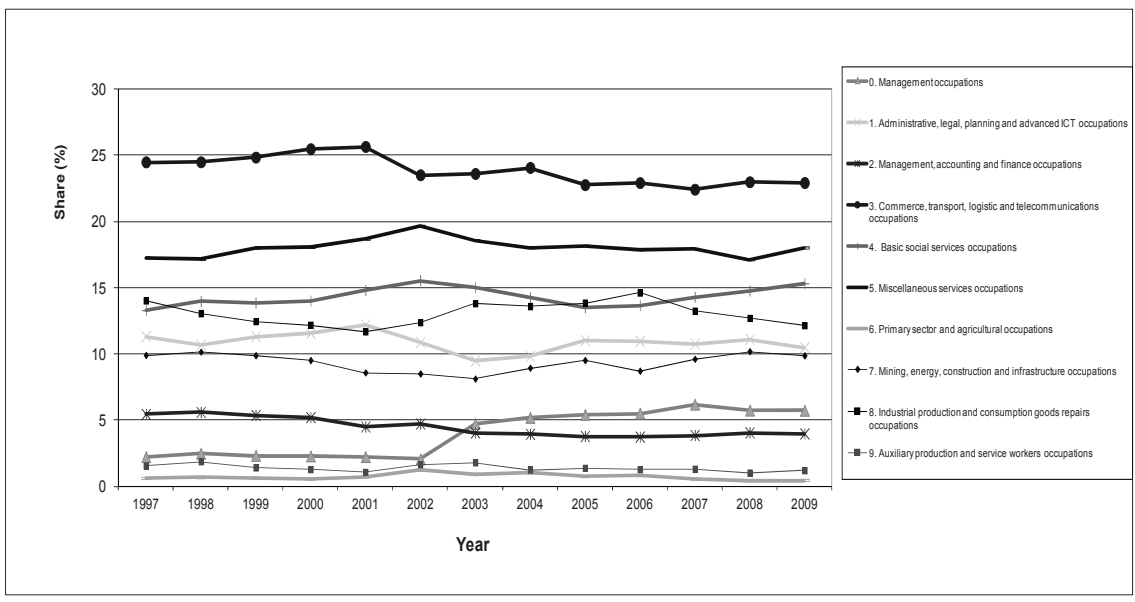

Source: INDEC, Sample Encuesta Permanente de Hogares and authors' calculations.

\section{IV.PRODUCTIVITY AND HOURS WORKED IN THE ARGENTINE LABOR MARKET}

This section extends the analyses of changes in the occupational composition of hours worked between 1997 and 2009. The reason for conducting an analysis of hours worked is to ensure that labor demand is measured more accurately, particularly across different types of occupations as pointed out by Wooden (2000). For example, average hours worked in management, administrative and professional occupations tend to be higher than in lower-skilled occupations. For example, in Australia employees in these positions tend to work longer hours without pay. We assume that this process also occurs in Argentina. In lower-skilled occupations such as industrial production and consumption goods repairs and sales, hours worked tend to be smaller because of the high incidence of precarious forms of employment. This is common in Australia, and it can be assumed to be more prevalent in developing economies such as Argentina. Finally, another advantage of looking at the occupational change in terms of hours worked is that these serve as a proxy for productivity. The analysis that follows looks at the skill composition of employment by aggregating the four skill categories described in Table 1 of the CNO. Because non-qualified occupations occur in all 
of the nine categories of the $\mathrm{CNO}$, these are proportionately distributed between professional, technical and labor occupations. Using our classification, we can see that between 2003-09 all occupations increased. The important change to note is that at first sight, the growth in employment has been stronger in occupations that require higher skills levels relative to those that require lower skills levels (i.e. job categories 1, 2, 3 and 4). This can be seen by the strong growth in employment numbers as detailed in Table 3 .

When we extend our analysis in terms of skill categories, the trends show clear signs of upskilling for 2003-2009, but not for 1997-2003, given that this period was characterized by economic hardship in Argentina. Table 5, shows signs of downskilling as a result of a faster growth in hours worked in high skilled occupations such as professionals and technical jobs (categories 1 and 2). This is also reflected in terms of the net share growth in column 15), indicating a decline in the top two skilled categories (categories 1 and 2) and a rise in the lowest one (category 3 - labor occupations. These trends indicate that in terms of productivity Argentina is not as productive as it could potentially be. A reason for this might be explained by the nature of Argentina's highly regulated labor force.

\section{CONCLUSION}

The authors are quite cautious about the conclusions, particularly because of the quality of Argentine data especially since 2006. Of late a number of surveys have come into question (e.g. Gasparini, 2010). This is quite an alarming development, given that Argentina has had a history of excellence in terms of data collection methodology, particularly when compared to other parts of Latin America. We also believe that this paper could well be enriched with an analysis of the evolution of wages in each of the categories analysed. Indeed, an extension of this would be to analyse and investigate the skill biased technological change hypotheses (SBTC) in Argentine occupations. For this type of analysis a richer source of occupational data would be required. One approach would be to use that conducted by Esposto (2008a) and Pappas (2001). We think that census data for Argentina is an avenue to achieving this goal ${ }^{3}$.

Nevertheless, we believe given the data available, that in the Argentine labor market context, the demand for labor as measured by hours worked, instead

\footnotetext{
${ }^{3}$ The authors are in the process of analysing these issues.
} 
of favouring the most skilled, happens to be favouring the least skilled. This process of deskilling occurs equally for both men and women. This is in sharp contrast to the experience of comparable developed countries such as Australia, where demand favours the most skilled (Wooden, 2000; Esposto, 2008a). This implies a sustained process of deskilling in the Argentine labor force which is likely to make it a less competitive nation, in an increasingly competitive global economy, where the edge is often obtained by nations whose investment in human capital development is a priority.

Furthermore, between 2003-09 these trends of downskilling in Argentina are quite alarming, particularly because they occurred over a period of strong economic growth. Growth in the share of employment in low-skilled jobs indicates that the demand for skills is favouring low level paid jobs, indicating that a process of upskilling is not occurring in the Argentine labor market. This is in marked contrast to the trends seen in many developed economies and the net effect of these trends is increasing levels of inequality. 


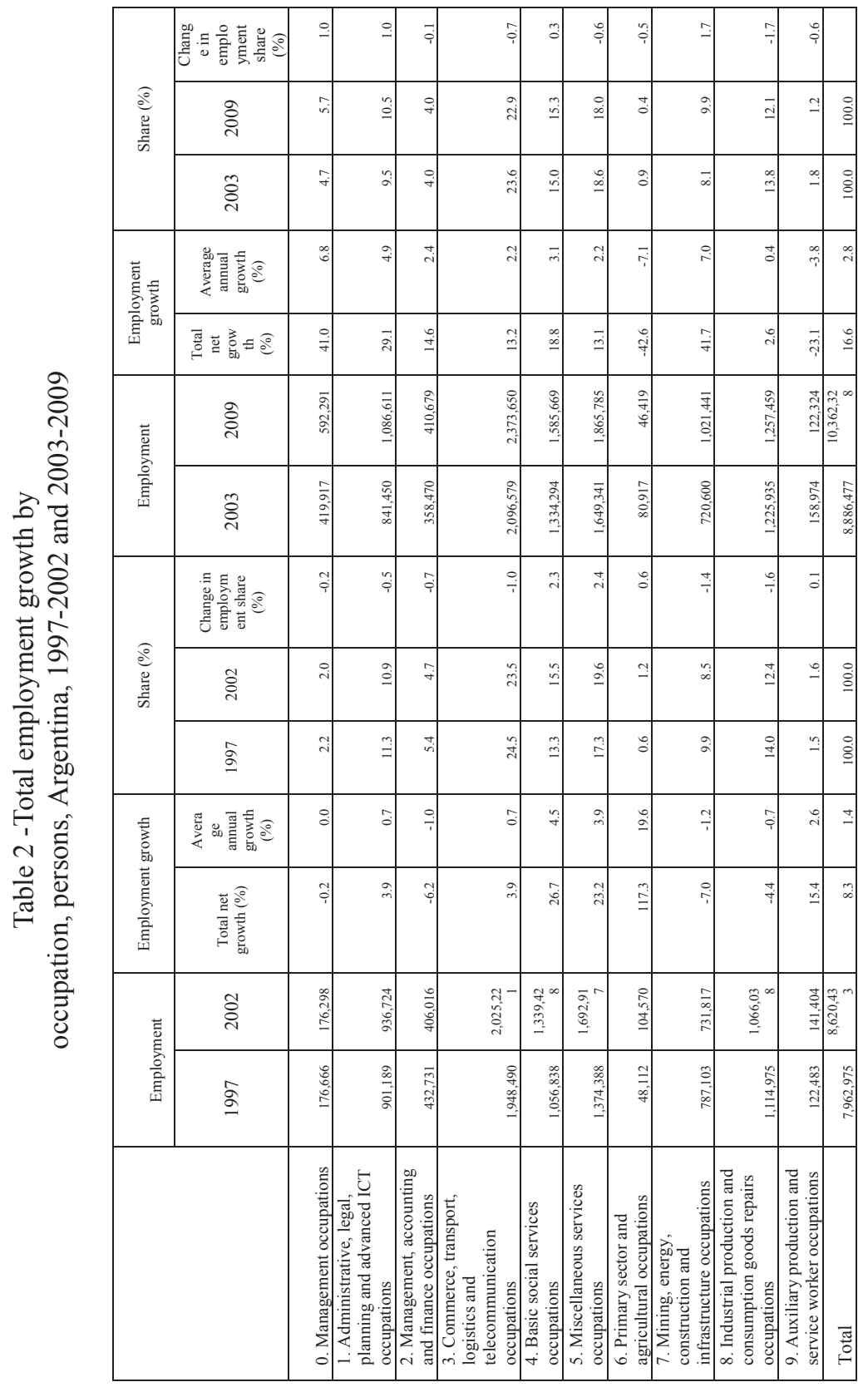

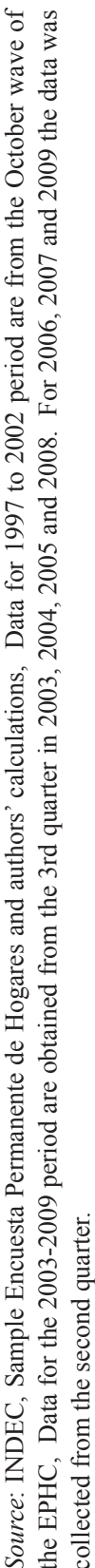


ESTUDIOS ECONOMICOS

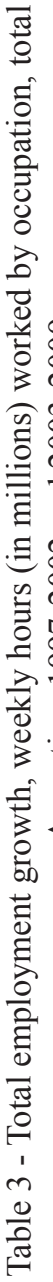

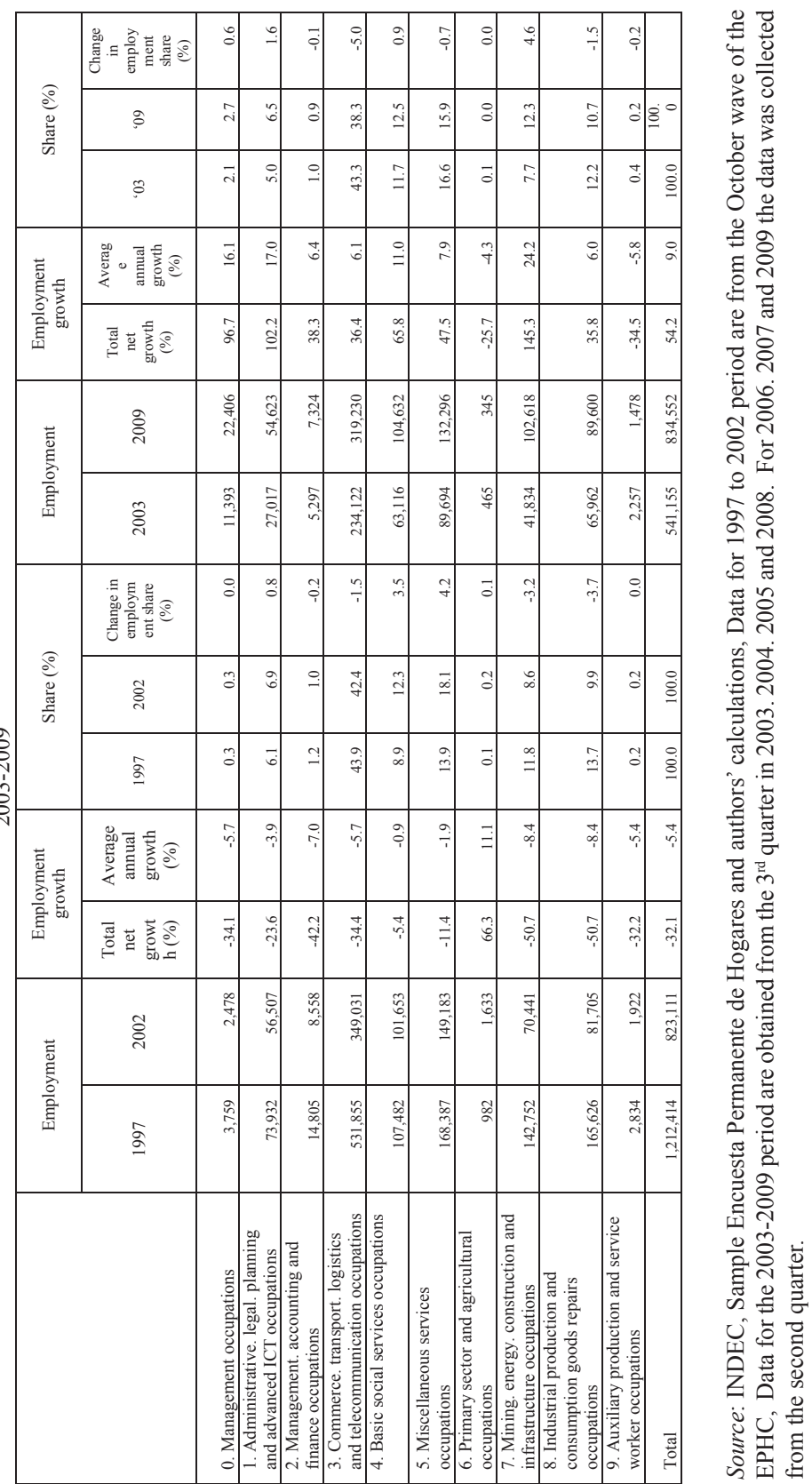



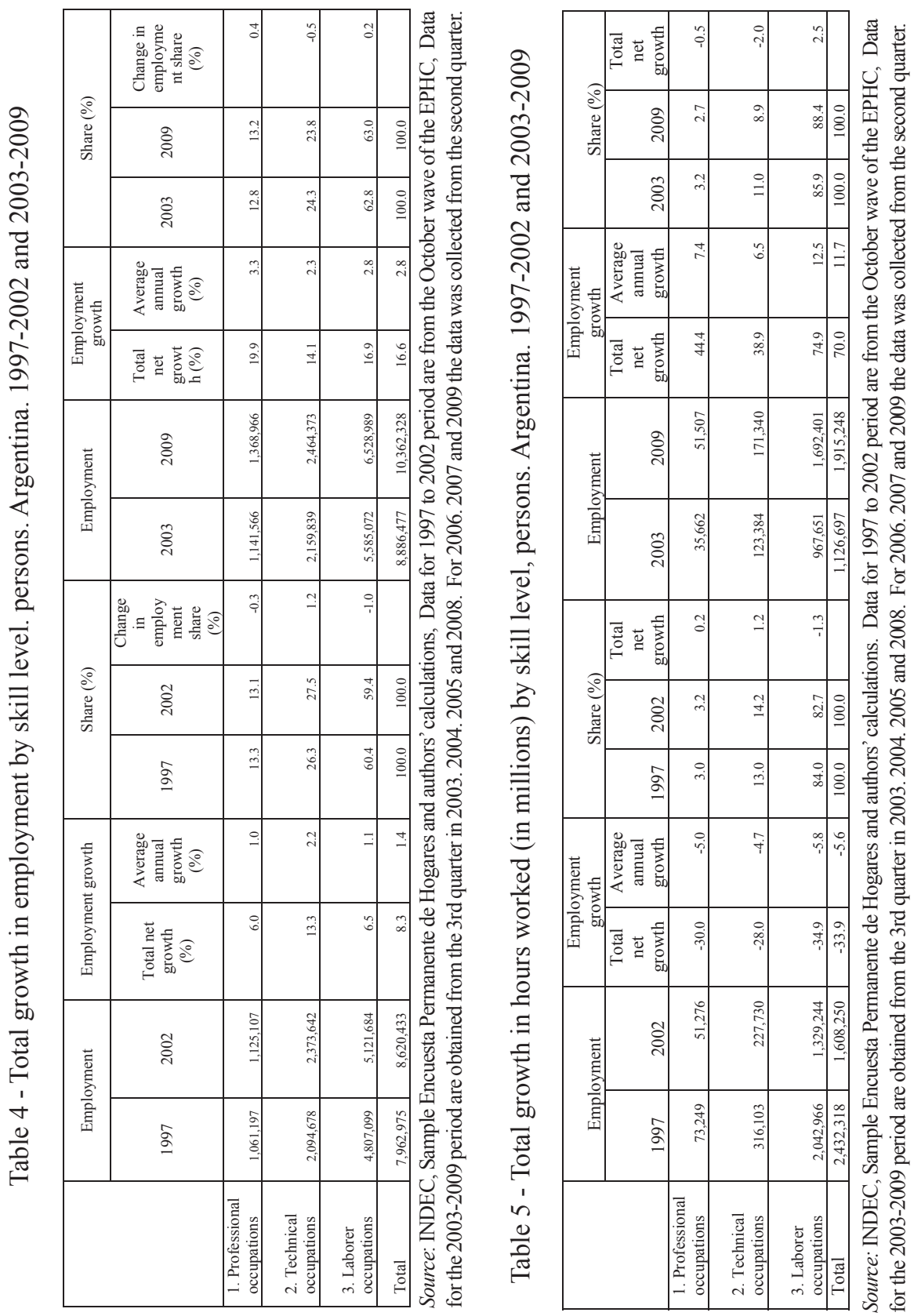
Table 6 - Total employment and total aggregate hours growth by skill level category. Australia. August 1989 to August 2002

\begin{tabular}{|l|c|c|c|c|}
\hline \multicolumn{1}{|c|}{ Skill level category } & $\begin{array}{c}\text { Employment } \\
\text { growth (\%) }\end{array}$ & $\begin{array}{c}\text { Aggregate } \\
\text { hours growth } \\
(\%)\end{array}$ & $\begin{array}{c}\text { Change in } \\
\text { employment share } \\
(\%)\end{array}$ & $\begin{array}{c}\text { Change in } \\
\text { aggregate hours } \\
\text { share (\%) }\end{array}$ \\
\hline I Managers/professionals & 63.7 & 57.7 & 6.3 & 7.2 \\
\hline II Associate professionals & 22.0 & 28.3 & -0.2 & -6.1 \\
\hline III Skilled vocations & -14.0 & -13.4 & -6.6 & 1.0 \\
\hline IV Intermediate skills & 31.6 & 23.8 & 1.6 & -3.0 \\
\hline V Elementary skills & 17.6 & -0.4 & -1.1 & \\
\hline Total & 24.0 & 19.1 & & \\
\hline
\end{tabular}

Source: Esposto, (2008a. p. 205).

\section{BIBLIOGRAPHIC REFERENCES}

ABS, (1997), "Australian Standard Classification of Occupations. Second Edition", cat. (1220.0), Australian Bureau of Statistics, Canberra.

Acemoglu, D., (2002), "Technical Change, Inequality. and the Labor Market", Journal of Economic Literature, Vol. 40. (1), pp. 7-72.

Aungles, P., Dearde, L., Karmel, T. and Ryan, C., (1993), "Through a Rear-View Mirror Darkly: Occupational Change. 1971-1986". Australian Bulletin of Labor. vol. 19. no. 2. pp. 97-113.

Berman, E., Bound, J. and Machin, S., (1998), "Implications of Skill Biased Technological Change: International Evidence", Quarterly Journal of Economics, Vol. 113, (4), pp. 1245-1279.

Colecchia, A. and Papaconstantinou., G., (1996), "The Evolution of Skills in OECD Countries and the Role of Technology", STI Working Paper 1996/8,

Organisation for Economic Co-operation and Development, Paris.

Commonwealth of Australia, (2002), "Safety Net Review - Wages 2001-2002",

Commonwealth Submission, Department of Employment and Workplace Relations, Canberra.

Cully. M., (1999), "AMore or Less Skilled Workforce? Changes in the Occupational Composition of Employment 1993 to 1999", Australian Bulletin of Labor, Vol. 25, (2), pp. 98-104. 
Dunlop, Y. and Sheehan, P., (1998), "Technology. Skills and the Changing Nature of Work", in Sheehan, P. and Tegart, G. (eds), Working for the Future: Technology and Employment in the Global Knowledge Economy, Victoria University Press, Melbourne.

Esposto, A., (2008a), "Dimensions of Earnings Inequality in the Labor Market: The Australian Experience”, VDM Verlag Dr Müller, Saarbrücken, Germany.

Esposto, A., (2008b), "Skill: An Elusive and Ambiguous Concept in Labor Market Studies", Australian Bulletin of Labor, Vol. 34, (1), pp. 100-124

Esposto, A. and Tohmé, F., (2009), "Drifting Apart: The Divergent Development Paths of Argentina and Australia", VDM Verlag Dr Müller, Saarbrücken, Germany.

Esposto, A., and Abbott, M., (2011), "Human Capital: A Comparative Study of the Skill and Knowledge intensity of Work in Australia and New Zealand", The New Zealand Journal of Applied Business Research, Vol. 9, (1), pp. 25-45.

Gasparini, L., (2010), "Argentina experimentó un fracaso distributivo como pocos países en el mundo". Disponible en: http://www.clarin.com/zona/ Argentina-experimento-fracaso-distributivo-paises_0_313168824.html., accessed 21 August, 2010.

Gasparini, L. and Cicowiez, M., (2007), "The Socio-Economic Conditions in Argentina", paper presented to John Fogarty Seminar, University of Buenos Aires, 26-27 April.

Gerchunoff, P. and Fajgelbaum, P., (2005), "Two Distant Cousins: An Essay on the Comparative Economic History of Argentina and Australia", Fundación PENT, Buenos Aires.

Gerchunoff, P. and Fajgelbaum, P., (2006), "Por Que Argentina No Fue Australia? Una Hipótesis Sobre un Cambio de Rumbo", Siglo XXI Ediciones, Buenos Aires.

INDEC, (2003), "La Nueva Encuesta Permanente de Hogares de Argentina", Instituto Nacional de Estadística y Censos, Buenos Aires, Disponible en: www.indec.mecon.ar/nuevaweb/cuadros/4/Metodologia_EPHContinua. pdf, accessed 4 May 2010.

INDEC, (2009), "Ponderación de la muestra y tratamiento de los valores faltantes en lasvariables de ingreso en la Encuesta Permanente de Hogares", Encuesta Permanente de Hogares, Dirección de Metodología Estadística - Dirección de Encuesta Permanente de Hogares, Instituto Nacional de Estadística y Censos, Buenos Aires, Disponible en: www.indec.gov.ar, accessed 10 May 2010,

Keating, M., (2003), "The Labor Market and Inequality", Australian Economic Review, Vol. 36, (4), pp. 374-396. 
Pappas, N.. (2001), 'Earnings Inequality and Skill'. in Borland, J., Gregory, B. and Sheehan, P. (eds), Work Rich. Work Poor: Inequality and Economic Change in Australia, Centre for Strategic Economic Studies, Victoria University, Melbourne.

Müller, A. and Lavopa, A., (2007), "Un Sistema de Análisis del Mercado de Trabajo Argentino. mediante Técnicas de Insumo-Producto", Centro de Estudios sobre Población. Empleo y Desarrollo, Buenos Aires, Disponible en: http://www.econ.uba.ar/www/institutos/economia/Ceped/publicaciones/ dts/DT10\%20\%20Muller\%20Lavopa.pdf, accessed 3 August 2010.

OECD, (1996), "Technology. Productivity and Job Creation", Vols 1 and 2, Organisation for Economic Co-operation and Development, Paris.

Sheehan P., (2001), "The Causes of Increased Earnings Inequality: The International Literature". in Borland. J., Gregory, B. and Sheehan, P. (eds.), Work Rich. Work Poor: Inequality and Economic Change in Australia, Victoria University, Melbourne.

VandenHeuvel, A. and Wooden, M., (2000), "Diversity in Employment Arrangements", in Mangan, J. (ed.) Understanding and Reducing Unemployment: National and State Perspectives, Office of Economic and Statistical Research, Queensland Treasury, Brisbane.

Wooden, M., (2000), "The Changing Skill Composition of Labor Demand,. Australian Bulletin of Labor, Vol. 26, (3). pp. 191-198. 